No relationship between the placental site and the duration of pregnancy or the length of labour was found.

ADDENDUM.-One objection to the present study is that the assessment of the length of labour when the placenta has partially extended on to the uterine fundus may not adequately test Csapo's hypothesis (personal communication, 1961) as he postulates an effect only when the placenta is completely fundal. Nevertheless, there were five completely fundal placentae in the present series, and the length of labour was very short in two of these cases ( 2 and $2 \frac{1}{2}$ hours).

\section{REFERENCES}

Bieniarz, J. (1959). Amer. J. Obstet. Gynec., 78, 385.

Csapo, A. (1956). Amer. J. Anat., 98, 273.

Fell (1961). Ciba Foundation Study Group, No. 9, p. 3.

Fell, M. R. (1956). J. Obstet. Gynaec. Brit. Emp., 63, 760.

Kushnirskaya, E. S., and Ivanova, E. F. (1958). Akush. $i$ Ginek., 34, No. 1 , p. 35

Pinkerton, J. H. M. (1961). Ciba Foundation Study Group, No. 9, p. 82.

Ranney, B. (1956). Amer. J. Obstet. Gynec., 71, 1049.

Stevenson. C. S. (1949). Ibid., 58, 432.

- (1950). Ibid., 60, 41.

Torpin, R., and Faulkner, A. H. (1957). J. Obstet. Gynaec. Brit. Emp., 64, 582.

Whitehead, A. S. (1953). Ibid., 60, 854

\title{
BLOOD GROUPS AND DISEASE: PREVIOUS TRANSFUSION AS A POTENTIAL SOURCE OF ERROR IN BLOOD TYPING
}

\author{
C. A. CLARKE, M.D., F.R.C.P. \\ R. B. MCCONNELL, M.D., M.R.C.P. \\ Department of Medicine, University of Liverpool \\ AND , \\ P. M. SHEPPARD, M.A., D.Phil. \\ Sub-Department of Genetics, University of Liverpool
}

BY

W. T. A. DONOHOE, A.I.M.L.T.

J. H. MARTINDAle, M.B., Ch.B.

Liverpool Royal Infirmary

The frequent use of blood transfusion has introduced into blood-group surveys a potential source of error large enough to give misleading resalts. This applies especially to investigations concerned with disease, and in particular to conditions such as duodenal ulcer where transfusion is commonly undertaken both in medical and in surgical cases.

It has been known for a long time that transfused cells containing antigens which the recipient lacks can be detected serologically, and techniques based on this fact have been used in studying the survival of transfused cells (Mollison, 1962). This is of minor importance in clinical work because it involves only the A and B antigens and the $D$ antigen of the $R h$ system, and patients should never have received blood with these antigens unless they already possessed them. However, an initial error in D grouping, leading to an Rh-negative patient receiving $\mathrm{Rh}$-positive blood, could be perpetuated for a time, since subsequent tests with anti-D would give a positive reaction. In research work involving the $R h$ antigens other than $D$, as well as the MN and other blood groups, previous blood transfusion can lead to a serious misscoring of a patient's own blood groups.

It occurred to one of us (W.T. A. D.) that this potential source of error ought to be considered as an explanation of the statistically highly significant association between duodenal ulcer and CDe/CDE found by Buckwalter and Tweed (1962). We were led to this because on collecting blood (for a similar survey) from patients in medical and surgical wards we very soon found that some of them gave a mixed reaction, a proportion of the cells being agglutinated while some remained free. Such reactions found by the unwary or inexperienced could easily be scored as an uncomplicated positive.

We therefore first approached the matter as an in vitro problem, selecting donor blood of such antigenic composition that, theoretically, it could cause an apparent change in the antigens of the recipient; we used $1 \mathrm{ml}$. of the former to $9 \mathrm{ml}$. of the latter-for example, $1 \mathrm{ml}$. of CDe/cDE MM was added to $9 \mathrm{ml}$. of $\mathrm{CDe} / \mathrm{cde} \mathrm{NN}$. Twenty such investigations were made -14 where the $\mathrm{Rh}$ system alone could have been changed, 4 where the MN only was involved, and 2 where both could have been altered. It was found that the expected conversion always took place ; it was therefore decided to investigate the problem in vivo. The blood of patients who had been transfused was examined repeatedly in order to ascertain: (1) in what percentage of patients those lacking a particular antigen, and transfused with blood containing that antigen, there was a strong enough positive reaction to lead to an error in grouping (assuming that mixed agglutination was not recognized as such); and (2) how long after their transfusion these cells would continue to give a false-positive reaction.

Method.-Blood of patients sent to the laboratory of the Liverpool Royal Infirmary for routine grouping and cross-matching was, if $R h(D)$-positive, tested by us with anti-C, anti-E, anti-c, 2 anti-M, and 2 anti-N sera, and so also was the donor blood cross-matched with it. After the patients had been transfused, blood was taken from them at intervals for a period of a month and tested with the same antisera.

\section{Results}

The results are shown in Table I. It can be seen that in all the 11 patients (out of 12) who received blood containing an antigen which they did not already possess this antigen could be detected after the transfusion and, moreover, as little as 1 pint $(570 \mathrm{ml}$.) was effective.

Even though there were many free cells, there were always sufficient numbers of large agglutinates to lead to the scoring of the test as positive. Furthermore, in every case tested for four weeks after the transfusion these false-positive reactions were still being found.

\section{Discussion}

There are two questions arising out of these results. First, what deviations from the true blood-group frequencies in a series would be caused by different 
TABLE I.-Blood Groups Before and After Transfusion of the Amount of Blood Stated [Throughout This Paper Phenotypes Have Been Designated as Probable Genotypes]

\begin{tabular}{|c|c|c|c|}
\hline $\begin{array}{l}\text { Case } \\
\text { No. }\end{array}$ & $\begin{array}{c}\text { Patient } \\
\text { Pro-transfusion }\end{array}$ & Donor Blood & $\begin{array}{c}\text { Patient } \\
\text { Post-transfusion }\end{array}$ \\
\hline 1 & $\mathrm{CDe} / \mathrm{CDe} \mathrm{MM}$ & $\begin{array}{l}\text { cDE/cde NN } \\
\text { cDe/cde MN } \\
2 \text { pints (1,140 ml.) } \\
\text { of blood given }\end{array}$ & $\begin{array}{l}\mathrm{CDe} / \mathrm{cDE} \mathrm{MN} \\
\text { Has gained c, E, } \\
\text { and } \mathrm{N} \text { antigens }\end{array}$ \\
\hline 2 & CDe/cde NN & $\begin{array}{l}\mathrm{cDE} / \mathrm{cde} \mathrm{MM} \\
1 \text { pint ( } 570 \mathrm{ml} .) \text { of } \\
\text { blood given }\end{array}$ & $\begin{array}{l}\text { CDe/cDE MN } \\
\text { Has gained } \mathrm{E} \text { and } \\
\mathrm{M} \text { antigens }\end{array}$ \\
\hline 3 & cDE/cde MN & $\begin{array}{l}\text { CDe/CDe MM } \\
\text { CDe/cde MM } \\
2 \text { pints (1,140 ml.) } \\
\text { of blood given }\end{array}$ & $\begin{array}{l}\text { CDe/cDE MN } \\
\text { Has gained C } \\
\text { antigen }\end{array}$ \\
\hline 4 & cDE/cdo $\mathrm{MM}$ & $\begin{array}{l}\text { CDe/cDE NN } \\
\text { cDE/cde MN } \\
\text { cDE/cde MN } \\
\text { CDe/cde MN } \\
4 \text { pints (2,275 ml.) } \\
\text { of blood given }\end{array}$ & $\begin{array}{l}\mathrm{CDe} \text { 'cDE MN } \\
\text { Has gained C and } \\
\mathrm{N} \text { antigens }\end{array}$ \\
\hline 5 & CDe/cde MN & $\begin{array}{l}\text { CDe/CDe MM } \\
\text { cDE/cde MN } \\
\text { cDE/cde MN } \\
3 \text { pints (1,700 ml.) } \\
\text { of blood given }\end{array}$ & $\begin{array}{l}\mathrm{CDe} / \mathrm{CDE} \\
\text { Has gained } \mathrm{MN} \\
\text { antigen }\end{array}$ \\
\hline 6 & cDE/cde $\mathrm{NN}$ & $\begin{array}{l}\text { CDe/cde MM } \\
\text { CDe/cDE MN } \\
2 \text { pints (1,140 ml.) } \\
\text { of blood given }\end{array}$ & $\begin{array}{l}\mathrm{CDe} / \mathrm{cDE} \text { MN } \\
\text { Has gained C and } \\
\mathrm{M} \text { antigens }\end{array}$ \\
\hline 7 & $\mathrm{CDe} / \mathrm{cDE} \quad \mathrm{MN}$ & $\begin{array}{l}\text { CDelcde MN } \\
1 \text { pint }(570 \mathrm{ml}) \text { of } \\
\text { blood given }\end{array}$ & $\begin{array}{l}\text { CDe/cDE MN } \\
\text { Unaltered (neces- } \\
\text { sarily so) }\end{array}$ \\
\hline 8 & $\mathrm{CDe} / \mathrm{CDE} \mathrm{NN}$ & $\begin{array}{l}\text { CDe/cde MM } \\
\text { cDE/cde NN } \\
2 \text { pints (1,140 ml.) } \\
\text { of blood given }\end{array}$ & $\begin{array}{l}\mathrm{CDe} / \mathrm{CDE} \\
\text { Has gained } \\
\text { antigen }\end{array}$ \\
\hline 9 & $\mathrm{CDe} / \mathrm{CDe} \quad \mathrm{MM}$ & $\begin{array}{l}\mathrm{cDE} / \mathrm{cde} \text { MN } \\
\mathrm{CDe} / \mathrm{CDe} \mathrm{NN} \\
2 \text { pints (1,140 ml.) } \\
\text { of blood given }\end{array}$ & $\begin{array}{l}\text { CDe/cde MN } \\
\text { Has gained c, N } \\
\text { and d (pre-- } \\
\text { sumptive) anti- } \\
\text { gens }\end{array}$ \\
\hline 10 & cDE/cde NN & $\begin{array}{l}\text { CDe/CDe MN } \\
1 \text { pint (570 ml.) of } \\
\text { blood given }\end{array}$ & $\begin{array}{l}\text { CDe/CDE MN } \\
\text { Has gained C and } \\
\text { M antigens }\end{array}$ \\
\hline 11 & CDe/cde MM & $\begin{array}{l}\text { CDe/cDE MM } \\
\text { cde/cde MN } \\
2 \text { pints (1,140 ml.) } \\
\text { of blood given }\end{array}$ & $\begin{array}{l}\text { CDe/cDE MN } \\
\text { Has gained E and } \\
N_{\text {antigens }}\end{array}$ \\
\hline 12 & $\mathrm{CDe} / \mathrm{CDe} \quad \mathrm{MM}$ & $\begin{array}{l}\text { CDe/cde MN } \\
1 \text { pint (570 ml.) of } \\
\text { blood given }\end{array}$ & $\begin{array}{l}\text { CDe/cde MN } \\
\text { Has gained c, N } \\
\text { andd (presump- } \\
\text { tive) antigens }\end{array}$ \\
\hline
\end{tabular}

percentages of the patients having been transfused during the previous month ? Second, could previous transfusion account for the high $\mathrm{CDe} / \mathrm{cDE}$ frequency found in 1,029 duodenal ulcer patients by Buckwalter and Tweed (1962)? In order to work out the answer to the first question one can start with the blood-group frequencies in a population and calculate the effect of transfusing different percentages of them, assuming that the $\mathrm{Rh}$-positive blood donors come at random from the same population. As a basis for these calculations we chose the control series of Buckwalter and Tweed (1962), thus making further calculations unnecessary in considering the answer to the second question. In this series there are $15.5 \%$ cde/cde and $1.15 \% \mathrm{Cde} / \mathrm{cde}$ and cdE/cde people who in hospital would receive $\mathrm{Rh}$ negative blood. We are left, therefore, with $83.35 \%$ of patients liable to receive blood of the various Rh-positive types. Table II shows the results of the calculated frequencies which might be found assuming $100 \%, 50 \%$, and $33 \frac{1}{3} \%$ respectively of the ulcer patients had been transfused with 1 pint $(570 \mathrm{ml}$.) of blood during the month before their blood samples were collected. In the calculations it was assumed that the $\mathrm{Rh}$-positive (D) patients would receive any blood other than cde/cde but that $\mathrm{Cde} / \mathrm{Cde}$ and $\mathrm{cdE} / \mathrm{cde}$ people would always receive cde/cde blood. Any other likely assumption would make only a negligible alteration in the percentages shown.

It can be seen that the largest increase would occur in the frequency of $\mathrm{CDe} / \mathrm{cDE}$, mainly at the expense of $\mathrm{CDe} / \mathrm{CDe}$ and $\mathrm{CDe} / \mathrm{cde}^{*}$ There would be a compensating increase in the frequency of $\mathrm{CDe} / \mathrm{cde}$ at the further expense of $\mathrm{CDe} / \mathrm{CDe}$. The frequency of $\mathrm{CDe} / \mathrm{CDe}$ would be greatly diminished, as $73.79 \%$ of

TABLE II.-Calculated Changes in $R h$ and MN Blood-group Percentages According to Proportion of Individuals Transfused

\begin{tabular}{|c|c|c|c|c|c|}
\hline $\begin{array}{l}\text { Blood } \\
\text { Group }\end{array}$ & $\begin{array}{c}\text { Pre-trans- } \\
\text { fusion } \\
\text { (\%) }\end{array}$ & $\begin{array}{c}100 \% \\
\text { Transuised } \\
(\%)\end{array}$ & $\begin{array}{c}50 \% \\
\text { Transfused } \\
(\%)\end{array}$ & $\begin{array}{c}331 \% \\
\text { Transfused } \\
(\%)\end{array}$ & $\begin{array}{l}\text { D.U. of } \\
\text { Buckwalter } \\
\text { and Tweed } \\
\text { (1962) (\%) }\end{array}$ \\
\hline $\begin{array}{l}\text { CDe/CDe } \\
\text { CDe/cde } \\
\text { CDe/cDE }\end{array}$ & $\begin{array}{l}17 \cdot 51 \\
33 \cdot 15 \\
13.89\end{array}$ & $\begin{array}{r}3.72 \\
31.99 \\
43.32\end{array}$ & $\begin{array}{l}10.59 \\
32.67 \\
28.56\end{array}$ & $\begin{array}{l}12.90 \\
32.83 \\
23.67\end{array}$ & $\begin{array}{l}13.31 \\
33.82 \\
22.06\end{array}$ \\
\hline $\begin{array}{l}\text { cDE/cde } \\
\mathrm{cDE} / \mathrm{cDE}\end{array}$ & 14.63 & 4.08 & $9 \cdot 34$ & 11.09 & 13.02 \\
\hline $\begin{array}{l}\mathrm{cDe} / \mathrm{cde} \\
\mathrm{cde} / \mathrm{cde}\end{array}$ & $\begin{array}{r}4 \cdot 17 \\
15 \cdot 50\end{array}$ & $\begin{array}{r}0.24 \\
15.50\end{array}$ & $\begin{array}{r}2 \cdot 18 \\
15.50\end{array}$ & $\begin{array}{r}2.85 \\
15.50\end{array}$ & $\begin{array}{r}3.60 \\
13.22\end{array}$ \\
\hline $\left.\begin{array}{l}\text { Cde/cde } \\
\text { cdEE cde }\end{array}\right\}$ & $1 \cdot 15$ & $1 \cdot 15$ & $1 \cdot 15$ & $1 \cdot 15$ & 0.97 \\
\hline $\begin{array}{l}\text { MM } \\
\text { MN } \\
\text { NN }\end{array}$ & $\begin{array}{l}26.85 \\
55.26 \\
17.89\end{array}$ & $\begin{array}{r}7.22 \\
89 \cdot 57 \\
3.21\end{array}$ & $\begin{array}{l}17.03 \\
72.43 \\
10.55\end{array}$ & $\begin{array}{l}20 \cdot 30 \\
66.71 \\
12.99\end{array}$ & $\begin{array}{l}26.50 \\
56.41 \\
17.09\end{array}$ \\
\hline
\end{tabular}

the Rh-positive donor blood could cause these patients' $\mathrm{Rh}$ blood type to be changed. Similarly, the frequency of $\mathrm{cDe} / \mathrm{cde}$ would be greatly reduced as $95 \%$ of transfused bloods would introduce a new antigen.

In the last column of Table II are the frequencies found by Buckwalter and Tweed (1962) in 1,029 duodenal ulcer patients. Even though the CDe/cDE frequency they found is similar to what could be found if a third of their patients had been transfused, their frequencies of the other $\mathrm{Rh}$ groups are not quite as would be expected if this had been the case; in particular, there is not a large enough drop in the frequency of $\mathrm{cDE} / \mathrm{cde}$ and there is a decreased cde/cde frequency (but the sampling errors are large). The strongest argument against Buckwalter and Tweed's results being affected by previous transfusion is the almost unchanged MN frequency. However, the fact that there is a highly significant departure from the Hardy-Weinberg equilibrium in their $\mathrm{MN}$ system frequencies ( $\chi^{2}$ for 1 degree of freedom $=24,000, P$ $<0.001$ ) indicates either substantial errors in typing or a heterogeneous group among the controls. In the latter case there may well be a difference between the donor and recipient populations. Again, Buckwalter and Tweed's almost unchanged $M N$ frequencies in the patients might be accounted for if the anti-M and anti-N sera used were of the type for which the manufacturers recommend that "all weak reactions be ignored."

We feel that while it is possible that the high $\mathrm{CDe} /$ cDE frequency found in this series of duodenal ulcer patients may indicate that people of this genotype have an increased susceptibility to the disease, yet further study of the $R \mathbf{h}$ groups in duodenal ulcer patients is needed bearing the transfusion factor in mind.

\section{Summary}

Attention is drawn to the fact that transfusion of 1 pint $(570 \mathrm{ml}$.) of blood can lead to mistakes in scoring a patient's $R h$ and $M N$ genotype for at least four weeks. In surveys of hospital patients an erroneously high *Throughout this paper phenotypes have been designated as probable genotypes. 
frequency of $\mathrm{CDe} / \mathrm{CDE}$ and $\mathrm{MN}$ people may be found, unless care is taken to study only those who have not been transfused. Previous transfusion may possibly be the explanation of the high $\mathrm{CDe} / \mathrm{cDE}$ frequency found in duodenal ulcer by Buckwalter and Tweed (1962).

We are grateful to the Research Committee of the United Liverpool Hospitals under the chairmanship of Lord Cohen of Birkenhead, to the Medical Research Council, and to the Nuffield Foundation for generous grants towards this work.

ADDENDUM.-Since writing this paper we have Rhgrouped (1) a series of 139 duodenal ulcer patients while they were in hospital, (2) a series of 111 duodenal ulcer patients who have not been in hospital for at least a year, and (3) a control series of 256 . We found the CDe/cDF frequencies to be $26.62 \%, 16.21 \%$, and $12.89 \%$ respectively. After the blood groupings had been carried out we studied the case sheets of the first series and found that approximately $50 \%$ of the patients had had a recent previous blood transfusion. Our figures, therefore, are in agreement with the theoretical frequencies given in this paper and are further evidence of previous recent blood transfusion being able to account for Buckwalter and Tweed's (1962) finding of a high $\mathrm{CDe} / \mathrm{cDE}$ frequency in duodenal ulcer.

REFERENCES

Buckwalter, J. A., and Tweed, G. V. (1962). J. Amer. med. Ass.

Mollison, P. L. (1962), Blood Transfusion in Clinical Medicine, 3rd ed. Blackwell, Oxford.

\title{
TUBELESS GASTRIC SURGERY
}

\author{
BY \\ W. GARDEN HENDRY, F.R.C.S., F.R.C.S.Ed. \\ Consultant Surgeon, Highlands General Hospital, London
}

It would seem to be current surgical practice on both sides of the Atlantic to use a naso-gastric tube for stomach decompression before and after routine gastric surgery, and in one clinic at least (Farris and Smith, 1956), in order to avoid a naso-gastric tube, it is the practice to use an indwelling gastrostomy tube for a few post-operative days.

In this short paper I propose to present evidence that this is entirely unnecessary, certainly for partial gastric resection and after vagus-nerve resection with a "drainage" procedure.

Below are presented two well-documented series which were begun in 1947, and the same routine preoperative care is being used to-day-a span of almost fifteen years. The first series comprises 114 cases of Billroth I partial gastrectomy for duodenal ulceration and lesser-curve ulceration; the second series is one of 118 cases of vagus-nerve resection and Finney pyloroplasty for duodenal ulcer and lesser-curve ulcer lesions. During this period, although these two procedures have been the methods of choice, a small number of Polya partial gastrectomies, with both post-colic and ante-colic anastomoses, and 20 cases of vagus resection and gastrojejunostomy, have been done without having to retreat from the tubeless regime.

\section{The Regime \\ Cases without Gastric Delay}

These are patients in whom the barium-meal investigation shows no residue or an insignificant residue after five hours. These cases come to operation after an overnight fast, without any special "gastric" preparation and no intubation.

Post-operative regime after any of the operative procedures mentioned in the preceding paragraph is as follows. (1) No Ryle's tube is passed, and no intravenous or other parenteral fluid therapy is used. (2) No antibiotic therapy is used except for special indications. (3) After full recovery from anaesthesia, the following strict progressive fluid regime is begun: 1 st 24 hours, 1 oz. ( $28 \mathrm{ml}$.) of water hourly by mouth ; 2nd 24 hours, $2 \mathrm{oz}$. (57 ml.) of water hourly by mouth; 3rd 24 hours, $3 \mathrm{oz}$. (85 ml.) of water hourly by mouth ; 4th 24 hours, $4 \mathrm{oz}$. (114 ml.) of clear fluids hourly by mouth-these can include orange juice with glucose, tea, Bovril, etc. ; 5th 24 hours, a very light diet with the addition of such items as bread-and-butter, junket, jelly, ice-cream, and scrambled egg.

A first-stage gastric dietary regime is now followed, going on to third-stage gastric diet at the end of a week, and after a further week a normal diet can be cautiously started if no chronic ulceration is to be healed. If chronic ulceration is present the gastric dietary regime would be continued for three to four weeks before resuming a normal dietary regime.

\section{Cases with Gastric Delay}

These are cases evidenced by significant barium residue after five hours. They certainly require preparation for operation, with a high-calorie fluid regime with added vitamins, and gastric lavage twice daily until the washings are clean and odourless, usually after two or three days. Cleansing of a severely obstructed stomach may, however, require as long as a week. In these cases the correction of dehydration may need adequate amounts of routine intravenous glucose and saline to achieve fluid balance.

Following this preparation, the "tubeless" regime detailed above is given without variation, and the experience is that recovery is uninterrupted.

The two series are analysed from this aspect as follows :

\begin{tabular}{c|c|c|c|c|c}
\hline Series & $\begin{array}{c}\text { No. of } \\
\text { Cases }\end{array}$ & $\begin{array}{c}\text { Type of } \\
\text { Operation }\end{array}$ & $\begin{array}{c}\text { Cases of } \\
\text { Overt Gastric } \\
\text { Retention } \\
\text { (Pre-op.) }\end{array}$ & $\begin{array}{c}\text { Cases of } \\
\text { Failure of } \\
\text { Tubeless } \\
\text { Regime }\end{array}$ & Mortality \\
\hline 1 & 114 & $\begin{array}{c}\text { Billroth I } \\
\text { partial } \\
\text { gastrectomy } \\
\text { Vagus resection } \\
\text { and Finney } \\
\text { pyloroplasty }\end{array}$ & $\begin{array}{c}19 \\
(16.6 \%)\end{array}$ & 0 & $\begin{array}{c}1 \text { case } \\
0.98 \%\end{array}$ \\
\hline
\end{tabular}

Two Comments.-(1) In the four cases of failure of the tubeless regime there was temporary gastric discomfort and moderate distension which necessitated the passing of a Ryle's tube. With added experience I believe it is possible that these cases could have been as easily handled by a slowing of the fluid increments by mouth, or a discontinuance of all fluid by mouth for a few hours. None of these cases developed any severe abdominal complication. (2) The one death from an 